\title{
HEAT OF COMBUSTION AS THE KEY FIRE CHARACTERISTICS OF ELECTRICAL CABLES
}

\author{
Jozef MARTINKA $^{1 *}$, Peter RANTUCH ${ }^{1}$, Martina HLADOVÁ $^{1}$, \\ Janka SULOVÁ ${ }^{2}$, Aleš NEČAS ${ }^{1}$, Denis BENKO ${ }^{1}$, Karol BALOG ${ }^{1}$ \\ ${ }^{1}$ SLOVAK UNIVERSITY OF TECHNOLOGY IN BRATISLAVA, \\ FACULTY OF MATERIALS SCIENCE AND TECHNOLOGY IN TRNAVA, \\ INSTITUTE OF INTEGRATED SAFETY, \\ Ulica JÁna BotTu 2781/25, 91724 TRnaVA, SlovaKia \\ ${ }^{2}$ VUKI, A.S., RYBNIČNÁ 38, 83107 BRATISLAVA, SLOVAKIA \\ e-mail: jozef.martinka@stuba.sk, peter.rantuch@stuba.sk,martina.hladova@stuba.sk, \\ sulova@vuki.sk, ales.necas@stuba.sk,xbenkod@stuba.sk, karol.balog@stuba.sk \\ *corresponding author \\ Received: 24.04.2019, Accepted: 18.06.2019, Published: 25.07.2019
}

\begin{abstract}
This scientific study deals with investigation of the heat of combustion and effective heat of combustion of selected electrical cables. Two different electrical cables for rated voltage of $0.6 / 1 \mathrm{kV}$ were investigated. Both cables were power three-core with cross-section area of each core of $1.5 \mathrm{~mm}^{2}$. The cores of both cables were made of a bar cooper wire. Insulations of conductors of both cables were made of silane cross-linked polyethylene without any inorganic filler, while the bedding and outer sheath were made of polyethylene-based copolymer (the beddings were filled with two fillers - aluminium hydroxide and calcium carbonate, while the outer sheath were filled only with aluminium hydroxide). Reaction to fire class of both cables was $B 2_{c a}, s 1, d 0$, al. The main difference in the investigated cables was that the core of one of them was wrapped in a glass mica tape (this cable showed circuit integrity maintenance under fire conditions during 180 minutes). The heat of combustion and effective heat of combustion were determined by the oxygen bomb calorimeter according to the ISO 1716:2018 standard. The highest effective heat of combustion showed the insulation of wires (for both cables 42.47 $\pm 0.03 \mathrm{MJ} / \mathrm{kg}$ ), lower value showed outer sheath (interval form13.61 to $15.26 \mathrm{MJ} / \mathrm{kg}$ ) and the lowest value was determined for bedding (interval from 4.69 to $6.39 \mathrm{MJ} / \mathrm{kg}$ ). The effective heath of combustion per unit of length of both investigated cables lies in the interval from 1.37 to 1.38 $M J / m$. Therefore, there is no significant difference in effective heats of combustion of the electrical cables investigated.
\end{abstract}

\section{Key words}

Electrical cable, effective heat of combustion, fire load, fire risk, oxygen bomb calorimeter 


\section{INTRODUCTION}

The fire risk of each material and product can be expressed by the parameters that quantify the probability of the fire ignition and the impact of fire on the material or product in the environment. Probability of fire ignition is determined by both, human factor and ignition characteristics of a material or product. Human factor represents an individual chapter in fire protection, which will not be discussed in this scientific article. The key ignition characteristics that determine the probability of fire ignition of a material or a product include particularly flash ignition temperature, spontaneous ignition temperature and critical heat flux. The issue of ignition characteristics of materials and products (not only electrical cables) has been investigated in scientific works of, e.g., Emberley et al. [1], Meinier et al. [2], Rantuch et al. [3] and Zachar et al. [4]. Electrical cables differ from the majority of other materials and products by the fact that they themselves are the source of heat during operation, which can cause ignition of electrical cable or material on which or in which the electrical cable is installed. It is caused by Joule heating, which is produced when the electrical current flows through a conductor. Joule heating equals to the electrical resistance of electrical conductor multiplied by the square of the electrical current and time. Released heat from electrical cable which is due to the flow of electrical current is often expressed as Joule power defined as the electrical resistance of electrical conductor multiplied by the square of the electrical current. Joule heating and Joule power problem during the flow of electrical current through the electrical conductor and electrical cable have been studied by Duong et al. [5] and Kim et al. [6]. It is necessary to determine dimension of the electrical cables, at least their minimal cross-section, so that Joule power does not cause the damage or destruction of electrical installation or fire. Electrical cables are dimensioned by the material data of which electrical conductors are made (the most often copper or aluminium) and the material of which the insulation is made (e.g., polyvinylchloride or cross-linked polyethylene). Electrical cables are also dimensioned by the way of their installation (e.g., in the air, on the wall, in the wall, etc.) and the current load of an electrical cable according to the technical standards (e.g., according to IEC 60364-552:2009/Cor.1:2011 [7]). In addition to that, electrical cables are also dimensioned in terms of voltage drop (so that the voltage in the powered device does not fall below the prescribed value). The problem of voltage drop in electrical installation is resolved by technical standards, e.g. IEC 60364-5-52:2009/Cor.1:2011 [7].

Cable routes are projected in such a way that the standard operation of cable does not cause the exceeded of the highest allowed temperature of the core, that is the typical low voltage installation cables for the voltages $0.6 / 1 \mathrm{kV}$ at $90{ }^{\circ} \mathrm{C}$ max. However, when selecting the insulating and sheathing materials, the special conditions the cable can be exposed to must also be taken into account. These used to be characterised by manufacturers as the maximum allowed temperature of the core at the overload (short-term, max. tens of minutes), which is $120^{\circ} \mathrm{C}$ and maximum temperature at the short circuit for the duration of maximum 5 seconds $\left(250^{\circ} \mathrm{C}\right)$.

Effect of the fire of material or product is characterised by released heat, toxicity of combustion products and extinction coefficient of released smoke. Toxicity of combustion products of electrical cables (or polymer materials they are made of) has been investigated in the scientific works of, e.g., Kaufman et al. [8], Hirschler et al. [9], Gann et al. [10] and Einbrodt et al. [11]. The total smoke release, extinction coefficient and smoke opacity of electrical cables (or polymer materials they are made of) have been investigated in the scientific works of, e.g., Hirschler et al. [12] and Rao et al. [13]. The total smoke release determines the properties of a smoke layer. Decrease of a smoke layer below the critical value (e.g., $2.5 \mathrm{~m}$ ) is the key factor for the determination of the safe available evacuation time. In the simplified models, the height of a smoke layer is determined by the fire growth rate (which partially depends on the heat of 
combustion of material). Detail information about the simplified methods of time estimation needed to decrease the height of a smoke layer to the critical value and the resulting safe available evacuation time is provided e.g. in the scientific work by Pokorny et al. [14].

Effective heat of combustion of electrical cables, which is the basic input data for the calculation of the fire load and the fire risk of the fire compartment, is of the greatest importance for the fire safety design in buildings (structures) and the fire engineering. The heat of combustion and effective heat of combustion of electrical cable determined per unit length (not per unit mass) are of the highest informative value for the practical application in the field of the fire safety design in buildings (structures) and fire engineering. Despite that, only two fire characteristics are determined for electrical cables, nowadays.

The first basic fire characteristics of electrical cables is the reaction to fire class. Electrical cables are classified in terms of the requirements and criteria mentioned in EN 13501-6:2018 [15], and based on the test results according to the technical standards defined in the cited EN [15]. They are classified into seven classes of reaction to fire $A_{c a}, B 1_{c a}, B 2_{c a}, C_{c a}, D_{c a}, E_{c a}$ and $\mathrm{F}_{\mathrm{ca}}$, to four additional classifications for the smoke production $\mathrm{s} 1, \mathrm{~s} 1 \mathrm{a}, \mathrm{s} 1 \mathrm{~b}$ and $\mathrm{s} 2$, three additional classifications for the formation of burning droplets $\mathrm{d} 0$, $\mathrm{d} 1$ and $\mathrm{d} 2$, and three additional classifications for acidity of combustion products a1, a2 and a3. With regard to the effective heat of combustion (heat of combustion), the only conclusion which can be made based on the reaction to fire class is that the polymer components of electrical cable classified as $A_{c a}$ fire class have the heat of combustion of $2 \mathrm{MJ} / \mathrm{kg}$ maximum. For electrical cables with the reaction to fire class other than $\mathrm{A}_{\mathrm{ca}}$, it is not possible to assume the effective heat of combustion (heat of combustion) of their polymer components from the reaction to fire class. The cables classified as $\mathrm{A}_{\text {ca }}$ class do not contain polymer material; respectively these are protected from the effects of fire. Requirements for class $\mathrm{A}_{\mathrm{ca}}$ can be met by, e.g., thermocouples with the ceramic insulation or cables in a longitudinally welded metal tube. Conventional and minimally flexible metallic and optical data cables of the class $\mathrm{A}_{\mathrm{ca}}$ will probably never exist.

The second basic fire characteristic of electrical cables is circuit integrity maintenance of the electrical cable system during the fire. Requirements and test procedure are specified, e.g., in technical standards STN 92 0205:2014 [16], IEC 60331-21:1999 [17], IEC 60331-23:1999 [18] and IEC 60331-25:1999 [19]. Part 21 applies to the power cables up to $1 \mathrm{kV}$, part 23 to data cables and part 25 to optical cables. This division is related to the test conditions, since the metallic cables are tested under the rated voltage and the optical cables are evaluated for their ability to transfer the light signal. Circuit integrity data of cable systems is of no informative value as for the effective heat of combustion (heat of combustion) of electrical cables. Circuit integrity is standardly required only for the cable systems supplying power to the devices which have to provide function during the fire (e.g., evacuation lifts).

In the member states of the European Union, requirements of the CPR (Construction Products Regulation - EU 305/2011 [20]) regulation are introduced for the electrical cables. E.g., in Spain (after the transposing of the cited regulation CPR) electrical cables must have the reaction to fire class at least $C_{c a} s 1 b, d 1$, a1 in all public buildings and $D_{c a} s 2, d 2$, a2 in the private buildings. Currently, in the Slovak Republic and in the Czech Republic, legal or technical requirements (e.g., in the Slovak Republic STN 92 0203/O1:2013 [21] and in the Czech Republic Decree MV CR 23/2008 Sb. [22]) require reaction to fire class at least B2 ca, $\mathrm{s} 1, \mathrm{~d} 1$, a1 for the surface mounted unprotected electrical cables in the areas with high risk of fire for persons (especially in escape routes, nurseries and intensive care units).

The common disadvantage of the primary fire characteristics mentioned above is that it is not possible to use them as input data for the calculation of fire load and fire risk of the fire compartment. Even though, there is currently almost no available data about effective heat of combustion and heat of combustion of polymer components of electrical cables with the $\mathrm{B} 2 \mathrm{ca}$, s1, d1, a1 reaction to fire class. Therefore, the aim of the submitted scientific paper is to 
determine the heat of combustion and effective heat of combustion of polymer components of two electrical cables with the $\mathrm{B} 2_{\mathrm{ca}}, \mathrm{s} 1, \mathrm{~d} 1$, a 1 reaction to fire class. The attained data will be expressed in the form that will be directly applicable in further research of fire risk of electrical cables (for fire science), and the direct application in the fire safety of buildings and fire engineering.

\section{MATERIALS AND METHODOLOGY}

Two electrical cables for fixed installation, manufactured and supplied by ELKOND HHK, a.s. Company, Slovakia, were investigated.

The first investigated electrical cable labelled as 1-CXKH-V 3x1.5 P60-R (further referred to as $\mathrm{CXKH)}$ is a power three-core electrical cable for fixed installation. Based on reaction to fire, it is classified as $\mathrm{B} 2 \mathrm{ca}, \mathrm{s} 1, \mathrm{~d} 0$, a1 class. Circuit integrity maintenance of this cable during fire conditions according to IEC 60331-21:1999 [17] is 180 minutes, and circuit integrity of the cable system (with this cable) during fire according to STN 92 0203/O1:2013 [21] is 60 minutes. The cable is designed for the supply of electrical equipment working under fire conditions for at least 60 minutes. The cable can be surface mounted (unprotected by any protection layer, e.g. plaster) in the areas of high fire risk for persons. The rated cable voltage is $600 \mathrm{~V} \mathrm{AC} \mathrm{(alternating} \mathrm{current)} \mathrm{or} 1000 \mathrm{~V} \mathrm{DC}$ (direct current). It consisted of three copper wires wrapped in the glass mica tape and insulated by insulation of the silane cross-linked polyethylene. The cable sheath was made of a copolymer of ethylene filled with aluminium hydroxide $\left(\mathrm{Al}(\mathrm{OH})_{3}\right)$. Between the insulated wires and the sheath, there is a bedding formed by ethylene copolymer with a high content of $\mathrm{Al}(\mathrm{OH})_{3}$ and calcium carbonate $\left(\mathrm{CaCO}_{3}\right)$.

The other investigated electrical cable labelled as N2XH-J 3x1.5 RE (further referred to as $\mathrm{N} 2 \mathrm{XH}$ ) is a three-core power electrical cable for fixed installation. Based on the reaction to fire, it is classified as $\mathrm{B} 2_{\mathrm{ca}}, \mathrm{s} 1, \mathrm{~d} 0$, a1 class. The cable can be surface mounted (unprotected by any protection layer, e.g. plaster) in the areas with high fire risk for persons. The rated cable voltage was $600 \mathrm{~V} \mathrm{AV}$ or $1000 \mathrm{~V} \mathrm{DC}$. It consisted of three copper wires insulated by insulation of silane cross-linked polyethylene. The cable sheath was formed by ethylene copolymer filled with $\left(\mathrm{Al}(\mathrm{OH})_{3}\right)$. Between the insulated conductors and the sheath, there is a bedding formed by ethylene copolymer with a high content of $\mathrm{Al}(\mathrm{OH})_{3}$ and $\left(\mathrm{CaCO}_{3}\right)$.

The basic difference between the cables $\mathrm{CXKH}$ and $\mathrm{N} 2 \mathrm{XH}$ is that the cable $\mathrm{CXKH}$ maintains circuit integrity during fire (this functional resistance was achieved mainly due to the glass mica tape wrapped around the copper conductors in cable $\mathrm{CXKH}$ ). The basic parameters of the electrical cables investigated are stated in Table 1.

The resistant residues of polymer components the investigated cables are made of are given in Table 2. The resistant residue of insulation, bedding, and outer sheath, after exposure to a temperature of $600^{\circ} \mathrm{C}$ (at the time, when the mass of samples listed polymer components of the investigated cables reached a constant value) approximately correspond to the content of solid inorganic fillers in the listed polymer components.

Cross-sections of the investigated electrical cables are listed in Fig. 1. 


\begin{tabular}{|l|l|l|}
\hline Table 1 Basic parameters of the CXKH and N2XH cables & CXKH & N2XH \\
\hline Electrical cable & 150 & 148.3 \\
\hline Mass of cable per unit length $(\mathrm{g} / \mathrm{m})$ & 45.5 & 44.1 \\
\hline Mass of outer sheath per unit length $(\mathrm{g} / \mathrm{m})$ & 54.2 & 55.2 \\
\hline Mass of bedding per unit length $(\mathrm{g} / \mathrm{m})$ & 9.3 & 10.7 \\
\hline Mass of insulation per unit length $(\mathrm{g} / \mathrm{m})$ & 2.5 & - \\
\hline Mass of glass mica tape per unit length $(\mathrm{g} / \mathrm{m})$ & 38.5 & 38.3 \\
\hline Mass of copper per unit length $(\mathrm{g} / \mathrm{m})$ & 9.8 & 10.3 \\
\hline Cable diameter $(\mathrm{mm})$ & 2.5 & 2.5 \\
\hline Diameter of copper wire with insulation $(\mathrm{mm})$ & 1.38 & 1.38 \\
\hline Diameter of copper wire without insulation $(\mathrm{mm})$ & 1.50 & 1.50 \\
\hline Cross-section area of copper wire $\left(\mathrm{mm}^{2}\right)$ & & \\
\hline
\end{tabular}

Table 2 Resistant residues (after loading by the temperature of $600{ }^{\circ} \mathrm{C}$ ) of polymer components of investigated cables

\begin{tabular}{|l|l|l|}
\hline Electrical cable & CXKH & N2XH \\
\hline Resistant residue of insulation (mass \%) & 0 & 0 \\
\hline Resistant residue of bedding (mass \%) & 55 & 60 \\
\hline Resistant residue of outer sheath (mass \%) & 42 & 41 \\
\hline
\end{tabular}

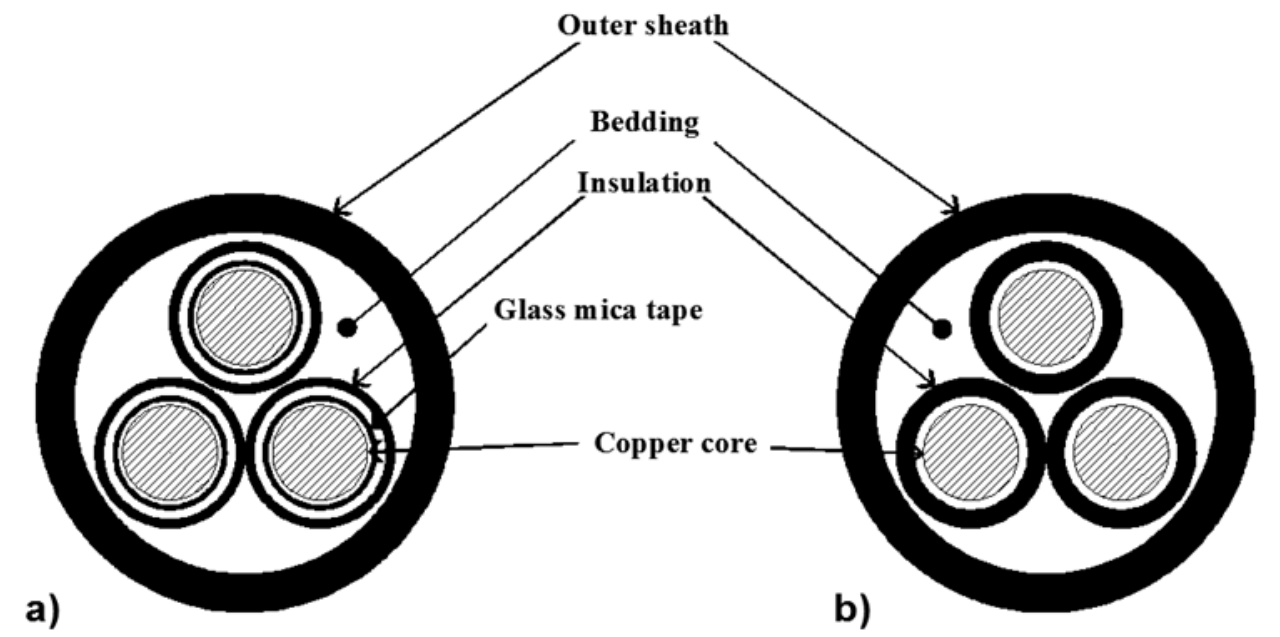

Fig. 1 Cross-section of investigated electrical cables; a) $\mathrm{CXKH}, b) \mathrm{N} 2 \mathrm{XH}$

The heat of combustion and effective heat of combustion of polymer components of the investigated electrical cables were determined by the oxygen bomb calorimeter according to the technical standard ISO 1716:2018 [23]. The test procedure of the experiment was also in accordance with the cited technical standard ISO 1716:2018 [23]. The mass of sample used for each experiment was $1 \pm 0.05 \mathrm{~g}$. Samples of insulation, bedding and outer sheath were obtained from the investigated cables by cutting. 


\section{RESULTS AND DISCUSSION ON RESULTS}

The heat of combustion of polymer components of the investigated electrical cables is listed in Table 3, and effective heat of combustion is given in Table 4. The resistant residue of polymer component after the determination of heat of combustion according to ISO 1716:2018 [23] is listed in Table 5.

\begin{tabular}{|l|l|l|}
\hline \multicolumn{3}{|c|}{ Table 3 Heat of combustions of polymeric parts of investigated cables } \\
\hline Electrical cable & CXKH & N2XH \\
\hline Insulation $(\mathrm{MJ} / \mathrm{kg})$ & $45.37 \pm 0.03$ & $45.37 \pm 0.03$ \\
\hline Bedding $(\mathrm{MJ} / \mathrm{kg})$ & $7.66 \pm 0.03$ & $5.99 \pm 0.02$ \\
\hline Outer sheath $(\mathrm{MJ} / \mathrm{kg})$ & $15.29 \pm 0.03$ & $16.96 \pm 0.07$ \\
\hline
\end{tabular}

As shown in Table 3, insulations of both investigated electrical cables showed the highest values of heat of combustion and effective heat of combustion. The reason of higher heat of combustion and effective heat of combustion of insulation in comparison with the bedding and the sheath (Table 3 and 4) was a high content of inorganic fillers in both, the bedding and the sheath (Table 2 and 5). Inorganic fillers reduce the heat of combustion and effective heat of combustion by two mechanisms. The first mechanism is based on the fact, that the increasing content of inorganic filler decreases the content of organic substances (per unit mass) which release heat at test according to ISO 1716:2018 [23]. The second mechanism is endothermic decomposition of inorganic fillers $\left(\mathrm{Al}(\mathrm{OH})_{3}\right.$ is decomposed into aluminium oxide and water, and $\mathrm{CaCO}_{3}$ is decomposed into calcium oxide and carbon oxide). Heat of combustion and effective heat of combustion (Tables 3 and 4) of insulation of the investigated cables correspond approximately to the average heat of combustion $(46.87 \pm 1.27 \mathrm{MJ} / \mathrm{kg})$ and effective heat of combustion $(43.83 \pm 0.69)$ of polyethylene published in the scientific works of Walters et al. [24], Karlsson and Quintiere [25], Drysdale [26] and Tsiamis et al. [27]. The reason of the difference between the heat of combustion and effective heat of combustion of insulations (determined in this scientific work) and the results of the cited scientific works is the fact, that polyethylene which is used in practice has different molecular weight. In addition to that, copolymers of ethylene are in practice often called polyethylene (however, the listed differences are insignificant in terms of fire science and fire engineering). For completeness it should be added, that the glass mica tape also showed heat of combustion approximately $3.64 \mathrm{MJ} / \mathrm{kg}$ and the resistant residue after the experiment according to ISO 1716:2018 [23] was approximately $94 \%$ (mass loss $6 \%$ approximately corresponds to the content of weight of used organic binder). However, its effect on the total heat of combustion and effective heat of combustion of the investigated electrical cable can be neglected due to the low value of the heat of combustion and effective heat of combustion of the glass mica tape and its negligible mass per unit length of the cable (Table 1).

\begin{tabular}{|l|l|l|}
\hline \multicolumn{3}{|c|}{ Table 4 Effective heat of combustion of polymeric parts of investigated cables } \\
\hline Electrical cable & CXKH & N2XH \\
\hline Insulation $(\mathrm{MJ} / \mathrm{kg})$ & $42.47 \pm 0.03$ & $42.47 \pm 0.03$ \\
\hline Bedding $(\mathrm{MJ} / \mathrm{kg})$ & $6.39 \pm 0.02$ & $4.69 \pm 0.02$ \\
\hline Outer sheath $(\mathrm{MJ} / \mathrm{kg})$ & $13.61 \pm 0.02$ & $15.26 \pm 0.07$ \\
\hline
\end{tabular}


The resistant residue of polymer components after the heat of combustion test according to ISO 1716:2018 [23] (Table 5) approximately corresponds to the resistant residues after the exposure to the temperature $600{ }^{\circ} \mathrm{C}$ (Table 2).

\begin{tabular}{|c|c|c|}
\hline Electrical cable & CXKH & N2XH \\
\hline Resistant residue of insulation (mass \%) & 0 & 0 \\
\hline Resistant residue of bedding (mass \%) & 56 & 55 \\
\hline Resistant residue of outer sheath (mass \%) & 42 & 41 \\
\hline
\end{tabular}

From a practical point of view, the heat of combustion and effective heat of combustion of cable per unit length find the most significant application in fire engineering and fire safety of buildings (structures) as well as in fire science. So, for the practical application, it is enough to know the overall length of electrical cable in the fire compartment and its heat of combustion or effective heat of combustion. The total amount of the heat released from the electrical cable into the fire compartment is then calculated as the total length of electrical cable in fire compartment multiplied by its effective heat of combustion. The heat of combustion and effective heat of combustion of the investigated electrical cables per unit length (calculated from the data in Tables 1, 3 and 4) are given in Table 6. In addition to the heat of combustion and effective heat of combustion per unit length, a good reporting value is also that of the heat of combustion and effective heat of combustion per unit area of electrical cables. This data allows a relatively simple application in the fire engineering and fire science (similarly to heat of combustion and effective heat of combustion per unit length), but, at the same time, it allows a very simple comparison of electrical cables of different diameters (but also comparison of electrical cables with other types of products). The heat of combustion and effective heat of combustion of the investigated electrical cables per unit area (calculated from the data in Tables 1 and 6) are shown in Table 7. The data in Tables 6 and 7 shows that the investigated electrical cables only slightly differ in the heat of combustion and effective heat of combustion (per both units of length and unit of area).

Table 6 Heat of combustion and effective heat of combustion of investigated electrical cables per unit length

\begin{tabular}{|l|l|l|}
\hline Electrical cable & CXKH & N2XH \\
\hline Heat of combustion per unit length $(\mathrm{MJ} / \mathrm{m})$ & $1.54 \pm 0.01$ & $1.57 \pm 0.01$ \\
\hline Effective heat of combustion per unit length $(\mathrm{MJ} / \mathrm{m})$ & $1.37 \pm 0.01$ & $1.38 \pm 0.01$ \\
\hline
\end{tabular}

Table 7 Heat of combustion and effective heat of combustion of investigated electrical cables per unit area

\begin{tabular}{|l|l|l|}
\hline Electrical cable & CXKH & N2XH \\
\hline Heat of combustion per unit area $\left(\mathrm{MJ} / \mathrm{m}^{2}\right)$ & $157.08 \pm 1.02$ & $152.29 \pm 0.97$ \\
\hline Effective heat of combustion per unit area $\left(\mathrm{MJ} / \mathrm{m}^{2}\right)$ & $139.74 \pm 1.02$ & $133.86 \pm 0.97$ \\
\hline
\end{tabular}

In fire safety in buildings (structures), fire engineering and also in fire science, wood is considered as a reference material. Therefore, by the comparison of the heat of combustion of material or product with wood, it is possible to decide whether this material or product 
represents (in terms of released heat) lower or higher fire risk than the reference material. In scientific work of Hasburgh et al. [28], effective heat of combustion (per unit area) for twenty of wood species and the agglomerated wood material were determined by the cone calorimeter (reported values are in the range from nearly $40 \mathrm{MJ} / \mathrm{m}^{2}$ to $170 \mathrm{MJ} / \mathrm{m}^{2}$ ). The reason of the reported high variance is the fact that the effective heat of combustion determined on the cone calorimeter (per unit area) depends on the heat flux and on the thickness of the sample (with the increasing thickness of sample also increases effective heat of combustion per unit area). In contrast, comparison of the data in Table 7 with the results of scientific work of Hasburgh et al. [28] shows that the effective heat of combustion of the investigated electrical cables (per unit area) corresponds approximately to the upper limit of the effective heat of combustion of agglomerated wood materials.

To compare the investigated electrical cables with other materials and products, it is important to have data about the heat of combustion and effective heat of combustion per unit area. In addition to that, the data about the average heat of combustion and effective heat of combustion of polymer components of electrical cable (average weighted by mass proportion of polymer components in electrical cable) and heat of combustion and effective heat of combustion of the whole electrical cable per unit mass, is equally important. The values (calculated from the data in Tables 1, 3 and 4) are listed in Table 8.

\begin{tabular}{|c|c|c|}
\hline Electrical cable & CXKH & N2XH \\
\hline $\begin{array}{l}\text { Average heat of combustion } \\
\text { of polymeric components }(\mathrm{MJ} / \mathrm{kg})\end{array}$ & $14.06 \pm 0.03$ & $14.22 \pm 0.04$ \\
\hline $\begin{array}{l}\text { Average effective heat of combustion } \\
\text { of polymeric components }(\mathrm{MJ} / \mathrm{kg})\end{array}$ & $12.48 \pm 0.02$ & $12.60 \pm 0.04$ \\
\hline $\begin{array}{l}\text { Heat of combustion } \\
\text { of the whole electrical cable }(\mathrm{MJ} / \mathrm{kg})\end{array}$ & $10.22 \pm 0.02$ & $10.55 \pm 0.03$ \\
\hline $\begin{array}{l}\text { Effective heat of combustion } \\
\text { of the whole electrical cable (MJ/kg) }\end{array}$ & $9.07 \pm 0.02$ & $9.35 \pm 0.03$ \\
\hline
\end{tabular}

For comparison, the results of the scientific work of Gunther et al. [29] showed that wood and the wood-based material exhibit the average heat of combustion $(18.77 \pm 0.68 \mathrm{MJ} / \mathrm{kg})$ and average effective heat of combustion $(17.41 \pm 0.67 \mathrm{MJ} / \mathrm{kg})$. The data of scientific work of Markova et al. [30] showed that the average heat of combustion of wood was $(19.81 \pm 1.07$ $\mathrm{MJ} / \mathrm{kg}$ ), and average effective heat of combustion of wood was $(18.23 \pm 1.08 \mathrm{MJ} / \mathrm{kg})$. When compared with the results of studies of Hasburgh et al. [28], Gunther et al. [29] and Markova et al. [30], the investigated electrical cables showed approximately the same fire risk (per unit area slightly higher and per unit mass slightly lower) in terms of released heat (per both unit area and unit mass), as the reference material in fire protection (wood). On the other hand, when compared with the results of scientific works of Walters et al. [24], Karlsson and Quintiere [25] and Tsiamis et al. [27], the investigated electrical cables (as a whole) showed significantly lower effective heat of combustion (fire risk in terms of released heat), as most of synthetic polymers. For comparison, the results of the scientific work of Martinka et al. [31] (for similar electrical cables) showed that the average heat of combustion of outer sheath is $16.5 \pm 0.3 \mathrm{MJ} / \mathrm{kg}$, the average heat of combustion of bedding is $7.4 \pm 0.2 \mathrm{MJ} / \mathrm{kg}$ and the average heat of combustion of insulation is $16.9 \pm 0.5 \mathrm{MJ} / \mathrm{kg}$. 


\section{CONCLUSION}

The heat of combustion and effective heat of combustion are the key fire characteristics which represent the input data for the calculation of the fire load and fire risk of the fire compartment. In the submitted scientific paper, heat of combustion and effective heat of combustion of polymer components of two halogen-free power electrical cables with reaction to fire class of $\mathrm{B} 2_{\mathrm{ca}}, \mathrm{s} 1, \mathrm{~d} 0$, a1 were determined (one investigated electrical was resistant to spread fire on the surface, and the other, in addition, showed the circuit integrity maintenance during the fire conditions). In this study, the methodology for the evaluation of effective heat of combustion and heat of combustion was developed and described, so that the data could be directly used in fire science, fire engineering, and also fire safety in buildings (structures). The specified methodology is based on the conversion of the heat of combustion and effective heat of combustion per unit length of electrical cable. This approach allows the calculation of fire load by simply multiplying the total length of the electrical cable in the fire compartment by its effective heat of combustion per unit length. The obtained results showed that effective heat of combustion of the investigated cables per unit length was $1.37 \pm 0.01 \mathrm{MJ} / \mathrm{m}$ (electrical cable with circuit integrity maintained during fire), respectively $1.38 \pm 0.01 \mathrm{MJ} / \mathrm{m}$ (electrical cable without circuit integrity maintained during fire). Effect of circuit integrity maintenance of the electrical cable during the fire on its effective heat of combustion is therefore negligible.

When comparing electrical cables with other materials (especially wood, which is the reference material in the fire safety in buildings), it is also important to express heat of combustion and effective heat of combustion per unit mass of polymer components of electrical cable and per unit mass of the whole electrical cable. The attained results showed, that average heat of combustion and effective heat of combustion of polymer components of investigated electrical cables were in the interval (14.06 to $14.22 \mathrm{MJ} / \mathrm{kg}$ - the heat of combustion), respectively (12.48 to $12.60 \mathrm{MJ} / \mathrm{kg}$ - effective heat of combustion). The heat of combustion and effective heat of combustion of electrical cables (as a whole) were in the range (10.22 to $10.55 \mathrm{MJ} / \mathrm{kg}$ - the heat of combustion), respectively ( 9.07 to $9.35 \mathrm{MJ} / \mathrm{kg}$ - effective heat of combustion). These values are lower than the heat of combustion and effective heat of combustion of most of organic polymers, and therefore, in terms of fire load, the investigated electrical cables show lower fire risk than the majority of organic polymers (the main reason is a high content of inorganic fillers in outer sheath and bedding).

These conclusions can be generalized for the electrical cables with the same reaction to fire class (B2 $\mathrm{ca}, \mathrm{s} 1, \mathrm{~d} 0$, a1), similar chemical composition of polymer components (thermoplastic on the basis of polyethylene) and their mass per unit length of electrical cable, similar diameter (from 9 to $11 \mathrm{~mm}$ ) and content of inorganic fillers.

\section{Acknowledgement}

This research output was supported by the Slovak Research and Development Agency under the contract No. APVV-16-0223.

\section{References}

[1] EMBERLEY, R., DO, T., YIM, J., TORERO, J., L. 2017. Critical heat flux and mass loss rate for extinction of flaming combustion timber. Fire Safety Journal, 91(1), 252-258. ISSN 0379-7112.

[2] MEINIER, R., SONNIER, R., ZAVALETA, P., SUARD, S., FERRY, L. 2018. Fire behaviour of halogen-free flame retardant electrical cables with the cone calorimeter. Journal of Hazardous Materials, 342(1), 306-316. ISSN 0304-3894. 
[3] RANTUCH, P., STEFKO, T., MARTINKA, J. 2018. Critical heat flux determination of electric cable insulation. Research papers Faculty of Materials Science and Technology Slovak University of Technology in Trnava, 26(42), 11-20. ISSN 1336-1589.

[4] ZACHAR, M., LIESKOVSKZ, M., MAJLINGOVA, A., MITTEROVA, I. 2018. Comparison of thermal properties of the fast-growing tree species and energy crop species to be used as a renewable and energy-efficient resource. Journal of Thermal Analysis and Calorimetry, 134(1), 543-548. ISSN 1388-6150.

[5] DUONG, T., T., TUNG, T., TANAKA, H., TSUZUKI, N., KAWAI, H., KIKURA, H. 2015. Effect of cooling temperature of electrodes on Joule-heating flow in cubic cavity. Progress in Nuclear Energy, 82(1), 165-175. ISSN 0149-1970.

[6] KIM, S., H., LEE, K., W. 2015. Numerical approach to joule heating analysis for electrical parts using MSC Marc. Journal of Mechanical Science and Technology, 29(5), 2081-2087. ISSN 1738$494 X$.

[7] IEC 60364-5-52:2009/Cor.1:2011. 2011. Low voltage electrical installations. Part 5-52: Selection and erection of electrical equipment - Wiring systems. 3rd ed. Geneva: International Electrotechnical Commission, 2011. $171 \mathrm{p}$.

[8] KAUFMAN, S., REFI, J., J., ANDERSON, R., C. 1991. USA approach to combustion toxicity of cables. Plastics, Rubber and Composites Processing and Applications, 15(3), 137-143. ISSN 09598111.

[9] HIRSCHLER, M., M., GRAND, A., F. 1993. Comparison of the smoke toxicity of four vinyl wire and cable compounds using different test methods. Fire and Materials, 17(2), 79-90. ISSN 10991018.

[10] GANN, R., G., PEACOCK, R., D., AVERILL, J., D., NYDEN, M., R. 2006. Smoke toxicity data for fire hazard and risk assessment of cable products. Journal of ASTM International, 3(2), 96-100. ISSN 1546-962X.

[11] EINBRODT, J., JESSE, H. 1984. Toxicity of gases from cable fires I. International Polymer Science and Technology, 11(12), 1-6. ISSN 0307-174X.

[12] HIRSCHLER, M., M., PURSER, D., A. 1993. Irritancy of the smoke (non-flaming mode) from materials used for coating wire and cable products, both in the presence and absence of halogens in their chemical composition. Fire and Materials, 17(1), 7-20. ISSN 1099-1018.

[13] RAO, B., N., ARUNJOTHI, R., SRINIVASAN, A., R. 2012. Assessing smoke and fire hazard of burning electric cables. In: 10th IEEE International Conference on the Properties and Applications of Dielectric Materials. Institute of Electrical and Electronics Engineers: India, Bangalore, pp. 14. ISBN 978-146732850-0.

[14] POKORNY, J., MOZER, V., MALEROVA, L., DLOUHA, D., WILKINSON, P. 2018. A simplified method for establishing safe available evacuation time based on a descending smoke layer. Communications - Scientific Letters of the University of Žilina, 20(2), 28-34. ISSN 13354205.

[15] EN 13501-6:2018. 2018. Fire classification of construction products and building elements. Part 6: Classification using data from reaction to fire tests on power, control and communication cables. Brussels: European Committee for Standardization, 2018. 32 p.

[16] STN 92 0205:2014. 2014. Fire behaviour of construction products and building constructions. Circuit integrity maintenance of cable systems. Requirements, testing, classification and application of test results. Bratislava: Slovak Office of Standards, Metrology and Testing, 2014. $14 \mathrm{p}$.

[17] IEC 60331-21:1999. 1999. Tests for electric cables under fire conditions. Circuit integrity. Part 21: Procedures and requirements. Cables of rated voltage up to and including 0.6/1.0 kV. 1st ed. Geneva: International Electrotechnical Commission, 1999. 19 p.

[18] IEC 60331-23:1999. 1999. Tests for electric cables under fire conditions - Circuit integrity - Part 23: Procedures and requirements - Electric data cables. 1st ed. Geneva: International Electrotechnical Commission, 1999. $19 \mathrm{p}$.

[19] IEC 60331-25:1999. 1999. Tests for electric cables under fire conditions - Circuit integrity - Part 25: Procedures and requirements - Optical fibre cables. 1st ed. Geneva: International Electrotechnical Commission, 1999. 13 p. 
[20] REGULATION (EU) No 305/2011 of the European Parliament and of the Council of 9 March 2011 laying down harmonised conditions for the marketing of construction products and repealing Council Directive 89/106/EEC.

[21] STN 92 0203/O1:2013. 2013. Fire protection of buildings. Continuous power supply responding for fire. Bratislava: Slovak Office of Standards, Metrology and Testing, 2014. 18 p.

[22] DECREE of MV CR 23/2008 Sb., on the technical conditions of fire protection of structures.

[23] ISO 1716:2018. 2018. Reaction to fire tests for products. Determination of the gross heat of combustion (calorific value). 4th ed. Geneva: International Organization for Standardization, 2018. $30 \mathrm{p}$.

[24] WALTERS, R., N., HACKETT, S., M., LYON, R., E. 2000. Heats of combustion of high temperature polymers. Fire and Materials, 24(5), 245-252. ISSN 1099-1018.

[25] KARLSSON, B., QUINTIERE, J., G. 1999. Enclosure Fire Dynamics. 1st ed. Boca Raton: CRC Press, 1999. 336 p. ISBN 978-084931300-4.

[26] DRYSDALE, D., D. 2016. Thermochemistry. In: Hurley, M., J., editor. SFPE Handbook of Fire Protection Engineering. 5th ed. New York: Springer, 2016. pp. 138-150. ISBN 978-1-4939-25643.

[27] TSIAMIS, D., A., CASTALDI, M., J. 2016. Determining Accurate Heating Values of NonRecycled plastics (NRP). 1st ed. New York: City University of New York, 2016. 27 p. ISBN

[28] HASBURGH, L., E., WHITE, R., H., DIETENBERGER, M., A., BOARDMAN, C., R. 2015. Comparison of the heat release rate from the mass loss calorimeter to the cone calorimeter for wood-based materials. In: Proceedings of Conference the Fire and Materials 2015. The 14th International Conference and Exhibition on Fire and Materials 2015. Interscience communications: United Kingdom, Hampshire, pp. 116-126. ISBN 978-151081410-3.

[29] GUNTHER, B., GEBAUER, K., BARKOWSKI, R., ROSENTHAL, M., BUES, C., T. 2012. Calorific value of selected wood species and wood products. European Journal of Wood and Wood Products, 70(5), 755-757. ISSN 0018-3768.

[30] MARKOVA, I., REH, R., OREMUSOVA, E. 2010. Calorimetric determination of combustion heat and net caloric value of selected solid organic fuels. In: Proceedings of Conference of the Fire Engineering 2010. The 3rd International Scientific Conference on Fire Engineering 2010. Technical University in Zvolen: Slovakia, Zvolen, pp. 235-242. ISBN 978-80-89241-38-5.

[31] MARTINKA, J., RANTUCH, P., SULOVA, J., MARTINKA, F. 2019. Assessing the fire risk of electrical cables using a cone calorimeter. Journal of Thermal Analysis and Calorimetry, 135(6), 3069-3083. ISSN 1388-6150.

\section{ORCID}

Jozef Martinka

0000-0002-0060-5785

Peter Rantuch

$0000-0001-5826-8323$

Karol Balog

0000-0002-0804-8338 